\title{
Moral Panics and Sexuality Discourse: The Oppression of Chinese Male Immigrants in Canada, 1900-1950
}

\author{
Stephanie Weber
}

Racial hierarchy in Canada between 1900 and 1950 shaped the way immigrant "others" were portrayed in White-Anglophone Canadian discourse. Crimes involving ethnic minorities were explained in racial and cultural terms that fed stereotypes and incited fears that served to marginalize and oppress minority groups, particularly people of colour. ${ }^{1}$ Chinese men, for instance, were targets of a racial and sexual othering that resulted in the distrust and oppression of this group. Moral and sexual threats posed by Chinese immigrants were part of an overarching fear of Chinese influence on white Canada known as the "Yellow Peril." The myth of the Yellow Peril "interwove all of the predominant discourse" in the early twentieth century, encouraging and exacerbating "accusations of vice, gambling, interracial seduction, drug use, and other 'moral offences"' against the Chinese in Canada. ${ }^{2}$ Racist perception of Chinese immigrant men in Canada helped to "shore up prevailing imperialist ideologies, marking out Asian societies as 'backward' and "primitive."'3 As Constance Backhouse explains, Chinese immigrant men were perceived to have "inferior moral standards"4 and, like other men of colour, were believed to be "incapable of controlling their sexual desires." ${ }^{5}$ Moral anxieties of this kind contributed to public support for racist legislation such as the Chinese Exclusion Act of 1923, and other laws and regulations which served to limit the entry of Chinese persons into Canada and to socially and economically marginalize those already settled.

As Stanley Cohen concludes in 1972's Folk Devils and Moral Panics, a moral panic refers to when "a condition, episode, person or group of persons emerges to become defined as a threat to societal values and interests." ${ }^{6}$ According to some

${ }^{1}$ Franca Iacovetta, Gatekeepers,: Reshaping Immigrant Lives in Cold War Canada (Toronto: Between the Lines, 2006), 20.

2 Madge Pon, "Like a Chinese Puzzle: The Construction of Chinese Masculinity in Jack Canuck," Gender History in Canada, Toronto: Copp Clark, (1996): 92.

${ }^{3}$ Constance Backhouse, "The White Womans Labor Laws: Anti-Chinese Racism in Early Twentieth-Century Canada," Law and History Review 14, no. 2

(1996): 334.

4 Backhouse, "White Womans Laws," 368.

5 Pon, "Construction of Chinese Masculinity," 93.

${ }^{6}$ As cited in Catherine Carstairs, “Deporting 'Ah Sin' to Save the White Race: Moral Panic, Racialization, and the Extension of Canadian Drug Laws in the 1920s," Canadian Bulletin of Medical History 16 no. 1 (1999): 68. 
historians, "moral panics reproduce and in some ways reify or worsen the social inequalities that gave rise to them in the first place." The perceived threat of Chinese men and an opium problem in Canada can be categorized using this term, as it has historically been used to "describe periods of public alarm about deviant behaviours," ${ }^{8}$ including drug use. The moral panic surrounding economic competition, drug use, sexual activity, and immigration policy associated with Chinese men in the early $20^{\text {th }}$ century "stigmatized an already marginalized Chinese population." ${ }^{\prime 9}$

Strict immigration laws meant an overwhelmingly male ${ }^{10}$ immigration of Chinese people, creating Chinese bachelor communities, made up largely of sojourners. ${ }^{11}$ The absence of Chinese women in immigrant communities had several effects on the dominant society. Firstly, those already inside the country were unable to reproduce with those of their own ethnicity, ${ }^{12}$ so white supremacist Canadians were able to uphold ideas of a racially exclusive Canada without fearing too much about an increase in the nonwhite Canadian population. Stringent regulations on immigration were the result of racism in governmental policy, so this outcome may have been purposeful. ${ }^{13}$ This racially-motivated regulation affected Chinese immigrants "at the most intimate level of existence," depriving them of "partnerships, family, and support systems." ${ }^{14}$ However, Chinese women's absence and many Chinese immigrants' bachelor status also "exacerbated the sexual apprehensions"15 of white Canadians because the inability of Chinese men to partner and reproduce with women of their own race meant that white women were an obvious option.

Despite the discourse of a sexual menace, Chinese men had largely not been seen as particularly threatening or sexually violent. The view of Chinese men as being so far removed from issues of sex and relationships contributed to attitudes that influenced allegations that "some white women viewed their Chinese domestic servants in such an asexual manner that they "employ[ed] Chinamen to scrub them whilst in their baths." ${ }^{16}$ Implicit in the construction of Chinese immigrant men as asexual or separate from issues of sex was their emasculation and the belief of some

${ }^{7}$ Carstairs, “Deporting 'Ah Sin,"' 68.

${ }^{8}$ Ibid, 67.

${ }^{9}$ Ibid, 68.

${ }^{10}$ Backhouse, "White Womans Laws," 321.

${ }^{11}$ Elise Chenier, "Sex, Intimacy, and Desire among Men of Chinese Heritage and

Women of Non-Asian heritage in Toronto, 1910-1950," Urban History Review 42 (2014): 29.

${ }^{12}$ Chenier, "Sex, Intimacy and Desire," 30.

${ }^{13}$ Ibid.

${ }^{14}$ Ibid, 31.

${ }^{15}$ Backhouse, "White Womans Laws," 341.

${ }^{16}$ Ibid, 336-337. 
white Canadians "that Chinese males were more 'feminine' than white men." ${ }^{17}$ This stereotype may have originated because of the frequency of Chinese men's occupation in "typically female occupations" such as food preparation and laundering, which were still seen as "extensions of women's work within the home."18 They were also designated into the "childish" position of houseboys, which "accentuated the perceived gap between Chinese and white men."19 This perception extended even to the 1902 Royal Commission on Asian Immigration into British Columbia, which "depicted [Chinese men] as members of a 'servile' and 'effete' civilization." ${ }^{20}$ Even in managerial positions, Chinese employers were seen as "timid," "unmuscular," and "unable to protect their female staff from the untoward behavior of white patrons." ${ }^{21}$ In 1928, Chatelaine magazine suggested that Chinese employers were unable to "surround female employees with security and good influences," speculating that "no white man intent on mischief would respect the authority of a Chinaman." ${ }^{22}$ This article glossed over the fact white patrons were the actual threat in this situation. ${ }^{23}$

These stereotypes served to dominate and oppress Chinese immigrant men. The construction of Chinese masculinity "made it impossible for men to acquire the virtues of white manhood." Since "the Chinese were ridiculed and condemned for their hard work;" and their "attempts at assimilation through Christianity were seen as ploys;" ${ }^{24}$ they were unable to escape their image as untrustworthy and cunning. Thus, they were essentially trapped into these stereotypes even if they made attempts to escape them. ${ }^{25}$

However, focusing on the "emasculation and feminization" that Chinese men faced does not take into account the other stereotypes they were cast as, such as that xthey were "sojourners, cheap labourers, and opium fiends." ${ }^{26}$ Therefore, we cannot take this feminization as "a sign of disinterest," as it is "apparent from the diametrical constructions of yellow [...] masculinity that sexuality is a common ingredient in racist ideology."27 Although prevailing societal perspectives "tended to strip Chinese males of their 'masculine' persona," ${ }^{28}$ there was a remaining and

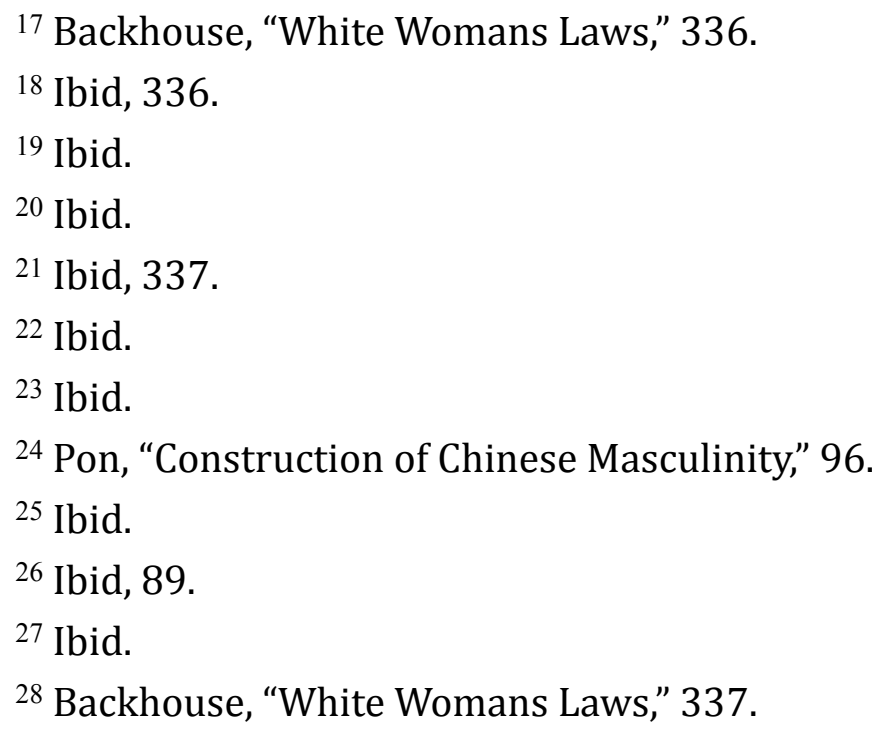


prevailing sense of apprehension about interracial sex. The seemingly contradictory ideas of asexuality and cunning sexually predatory Chinamen coexisted.

Therefore, some labour laws were implemented against Chinese businesses to "protect" white female employees under Chinese employment. These businesses were usually already struggling, and their situation was worsened by laws that forbade them from hiring white women, who were both cheap labour and more likely to attract white customers. ${ }^{29}$ The 1912 Saskatchewan Act to Prevent the Employment of Female Labour in Certain Capacities specifically targeted Asian employers, and was later modified to only encompass those of Chinese heritage. ${ }^{30}$ Many groups, including the National Council of Women of Canada, supported these laws and regulations. ${ }^{31}$ The NCWC actually carried out investigations of Chinese businesses to support the act, but found "no evidence of girls receiving harmful treatment" at the hands of Chinese employers. ${ }^{32}$ Despite this, sentiment within the group continued to specify that the laws were not created for a specifically discriminatory purpose "against an Oriental race" and that their sole resolution was the protection of white female workers. Importantly, the category of "white" had not previously encompassed working class women according to official, class discriminatory views, and their inclusion was one of the things this act specified. ${ }^{33}$

The reason for discriminating against Chinese business owners and putting legislation into place was a reaction to the economic competition they introduced, as measures such as the white women's labour laws made Chinese economic presence less of a threat to white businesses. Chinese men, to many white men, represented an introduction of cheap labour and services, which seemed to undermine white Canadian's economic power. It is apparent that this was where some of the support for discriminatory legislation originated, because this bill not only found support among protestant moral reformers and women's groups, but also in labour organizations and small business owners. ${ }^{34}$ The white male labour movement was fearful of economic competition particularly, and their heavy racial prejudice moved them to exclude Asian men from unions, as well as boycotting businesses that employed Asian labour, pressing for legislation to protect white men's jobs, and support the movement to prevent further immigration from Asia through legislation. ${ }^{35}$ The Saskatchewan Retail Merchants' Association supported bills for exclusion as a result of concerns about economic competition as well. ${ }^{36}$ The white women's labour laws specifically were devastating to the Chinese in ways that

\footnotetext{
${ }^{29}$ Backhouse, "White Womans Laws," 323.

${ }^{30}$ Ibid.

${ }^{31}$ Ibid, 341.

32 Ibid.

${ }^{33}$ Ibid, 362.

${ }^{34}$ Ibid, 345.

35 Ibid.

${ }^{36}$ Ibid.
} 
highlight the connection to economic competition concerns. Pervasive "racially discriminatory" attitudes meant that it was advantageous to have "white employees waiting tables," ${ }^{37}$ so forbidding white women from working storefront in Chinese businesses meant a reduction in customers. White women were also paid even lower wages than male Asian immigrants in the early $20^{\text {th }}$ century, and women were restricted significantly in types of jobs they could obtain, so they were an ideal source of labour for business owners looking to employ less expensive and more available workers. ${ }^{38}$ Restricting this resource meant a significant economic disadvantage for Chinese business owners. In addition, although the original white women's labour act excluded all men of Asian heritage, it was modified to delete all references to "Japan" because of protests from the Japanese government and Japan's presence as an "imperial power of relatively greater military and commercial significance than China," leaving "Chinese as the sole targeted group" as of January 11, 1913. ${ }^{39}$ Here, it is clear that economic interests still dictated much of the legislation implemented.

Perceiving the Chinese as a threat, and their opportunities for privacy as "convenient fronts" to do "nasty deeds" behind, fuelled the notion that the immigrants needed to be "policed and constantly observed." 40 This both "stigmatized the work Chinese men did in laundries and restaurants" 41 and fuelled support for immigration laws and head taxes so to stop immigration from China.

Possibly as a result of their bachelor status, Chinese men were perceived by many to pose "a moral and sexual threat to white women," ${ }^{42}$ so it was feared that beneath "the façade, or behind the partition" that was afforded by their business fronts, "Chinese men mocked white society and secretly hungered for white women." ${ }^{43}$ This perception was influential in much of the fear mongering and social activism against Chinese immigration, with a muckraking people's newspaper called Jack Canuck as one of its main purveyors. A recurring theme in Jack Canuck was that "Chinese men deviously hid their corruption, their vice, and their sexual hunger for white women" behind the façade of servility. ${ }^{44}$ One such article by Fred Jarrett suggested that girls should be careful of Chinatown because passing through it would subject them to the temptations and wiles of a race of people that were "loathsome beyond respect, and cunning beyond belief." ${ }^{45}$ Here, the idea of Chinese men as both devious and cunning behind their outside appearance is presented as a risk for white women,

${ }^{37}$ Backhouse, "White Womans Laws," 331.

${ }^{38}$ Ibid, 330.

${ }^{39}$ Ibid, 348.

${ }^{40}$ Pon, "Construction of Chinese Masculinity," 93.

${ }^{41}$ Ibid.

42 Ibid, 88.

${ }^{43}$ Ibid, 92.

${ }^{44}$ Ibid, 88.

${ }^{45}$ Quoted in Pon, "Construction of Chinese Masculinity." 88. 
and this racist ideology serves to create fear around a community of Chinese immigrants who were running businesses, living their lives and trying to survive.

In addition, Chinese workers were observed to smile frequently. Margaret Pon argues that white Canadians "were so intent upon dehumanizing and desexualizing the Chinese that they did not stop to consider why Chinamen smiled as they did," having interpreted their friendliness as a ploy or façade. Pon suggest that their expressions were the "smiles of labourers [...] who had to survive within and under an oppressive social system." The idea that Chinese men's friendliness was a "ploy" or "façade" inevitably meant that they must have been obscuring something about their true nature. The implication that Chinese immigrants were secretly traffickers and opium peddlers behind smiling faces and friendly storefronts meant a degree of suspicion about immigrant men's "façade" and a distrust of their "partition."

The press also contributed highly to racist perceptions of Chinese men. In the Toronto Star, "Chinamen" are referred to alongside white women almost always in a sexual or predatory light. Two short news articles articulate this portrayal in similar ways. The first, entitled "Soldier Husband Lives" from 1920, describes a woman whose husband was reported dead, who then worked for a Chinese man who "urged" her to marry him. She is quoted saying that she "did not want to marry the Chinaman." ${ }^{4}$ She is gratified that her first husband, upon his return from war, was willing to take her back and that she got custody of her child with her husband. Although it is difficult to ascertain the exact circumstances of the woman's relationship with the Chinese man, it is likely that the news coverage is biased against him to some degree. He is portrayed as coercing, and an inferior choice next to the woman's previous husband. It is unlikely that this was the nature of every relationship and marriage between white Canadian women and Chinese male immigrants. This article exemplifies the kinds of stories that the public was exposed to. ${ }^{47}$ The second short article's title, "Jealous Chinaman Murders White Woman," 48 is already telling of the media's perception of Chinese men. It is assumed in the article that the Chinese man is "jealous," although no reason is given for the dispute between him and the white girl that he shot. The article also makes reference to a "similar" murder that occurred in New York, appearing to stack up the evidence against Chinese men. It is clear that news coverage often contributed to a racist vision of Chinese male immigrants to North America.

Despite the prevailing attitudes of Chinese men's sexual deviancy, a range of consensual sexual and affective relationships were commonplace between Chinese immigrant men and white Canadian women. ${ }^{49}$ These situations, however, were

\footnotetext{
46 "Soldier Husband Lives," October 6, 1920, ProQuest Historical Newspapers: Toronto Star.

${ }^{47}$ Chenier, "Sex, Intimacy and Desire".

48 “Jealous Chinaman Murders White Woman," August 9, 1909, ProQuest Historical Newspapers: Toronto Star.

${ }^{49}$ Chenier, “Sex, Intimacy and Desire," 30.
} 
silenced by the increasingly prevalent view of Chinese men as cunning and predatory. According to Constance Backhouse, many white Canadians feared that the "indiscriminate use of drugs" would "dissolve boundaries between races," 50 therefore encouraging miscegenation. Since Chinese masculinity was so compromised in the public view, "sexually predatory"51 Chinese men were often associated with drugs, which were seen to corrupt and deceive white women into sexual relations. News reports and public discourse frequently linked incidents of rape to narcotics, often opium. Opium was "stereotypically (and often mistakenly) linked with the Chinese community," and was "thought to be capable of fueling 'flagging sexual energies,' transforming the asexual Chinese man into a sexually dangerous adversary." ${ }^{2}$ If Chinese male immigrants were thought to be "not manly enough to acquire the attentions of white women," public opinion concluded that they must be using "deceit and drugs" 53 to ensnare women.

Meanwhile, a heavily racialized "opium debate" about the perils of drugs and the threat they posed was being conducted, not ending until around 1923. The movement can be called a moral panic, as opium was often associated with Chinese immigrants and the catalyst for anti-Chinese legislation. Legal policies that the movement introduced included the right to "search people and places without a warrant and limiting the right to an appeal," 54 reducing the human rights of these immigrant Canadians even further. The drug panic effectively exacerbated "racial drama" that depicted Chinese men as "traffickers" who turned "innocent white youth" into "dope fiends." 55 Seeing opium as a primarily Chinese problem furthered the idea that the drugs, like the "people who used them, needed to be controlled and regulated." 56 This drive unfolded at the same time as a large scale movement to restrict Chinese Canadian's access to Canada, in areas of immigration, as well as schools and business. ${ }^{57}$ The racialization of the drug panic also explains why Chinese Canadians were so severely targeted by punitive measures while white "victims" were concentrated on as recipients of treatment and rehabilitation. ${ }^{58}$ The movement against drugs was largely spearheaded by women's groups, social service organizations, labor unions, fraternal societies, and church congregations, demanding harsh legislation and concentrating heavily on measures of Chinese exclusion. ${ }^{59}$ Edmonton feminist and political magistrate Emily Murphy's articles and

50 Backhouse, “White Womans Laws," 338.

${ }^{51}$ Ibid.

52 Ibid.

53 Pon, "Construction of Chinese Masculinity," 97.

54 Carstairs, “Deporting 'Ah Sin,'” 68.

55 Ibid, 69.

56 Ibid, 70.

${ }^{57}$ Ibid, 69.

58 Ibid.

${ }^{59}$ Ibid, 66. 
social activism influenced this movement heavily, blaming the Chinese for the menace and focusing on the protection of white females. ${ }^{60}$

Writers for Jack Canuck called for police to break down the doors of Chinese dens of iniquity and infamy, "kept for the purpose of ruining young Canadian girls."61 They argued that a "certain class" of white girls needed to be "saved" from frequenting Chinese "joints," and criminal charges had to be laid against the foreigners. The police and white men were encouraged to "step beyond the line" drawn by the "fiend"; to look beyond the "entertaining and attractive exterior" 62 of Toronto's Chinatown in order to expose the "unbelievable crime and vice behind its doors."63 Though incidents of white women being lured into these "dens of iniquity" 64 for the purposes of prostitution were rarely mentioned in anti-Chinese articles, this crime was implied. ${ }^{65}$ In the news, stories were often carried suggesting that Chinese "opium peddlars" had a "particular predilection for white women," whom they intended to "'enslave with the poppy,' 'defile with [their] embraces,' and 'prostitute to [their] countrymen."'66

Incorporations of this drug anxiety in prominent discourse meant that much of the press reinforced these racial stereotypes, which solidified public sentiment against the Chinese immigrant population. The Moose Jaw Evening Times warned readers of the "moral and intellectual decadence" posed by "the Yellow Peril."67 It was these journalistic narratives that allowed the stereotype to pervade so effectively. Reinforcements of the stereotype in popular culture were present in $\mathrm{Fu}$ Manchu books, as well as "radio plays, movies, Hilda Glynn Howard's 1921 novel The Writing on the Wall," Emily Murphy's 1922 "exposé" The Black Candle, and J.S. Woodsworth's Strangers Within Our Gates. ${ }^{68}$ It was easy, then, when a narrative of a "predatory Chinaman" who had "lured, drugged and raped an innocent white girl" arose, to perceive it as part of a "predictable script." 69

The Chinese men already in Canada during the opium scare were often subject to raids and "marches" where white savior Canadians would forcibly break into Chinese homes and businesses under the pretense of catching them with white women or drugs. The Moose Jaw Chief of Police Walter Palmer Johnson had

60 Carstairs, “Deporting 'Ah Sin,'” 71.

${ }^{61}$ Quoted in Pon, "Construction of Chinese Masculinity," 92.

62 Ibid.

63 Ibid.

${ }^{64}$ Ibid, 92.

65 Ibid.

66 Backhouse, “White Womans Laws," 339.

${ }^{67}$ Ibid, 333.

${ }^{68}$ Chenier, “Sex, Intimacy and Desire," 30.

${ }^{69}$ Mona-Margaret Pon, “The Case of the 'One Good Chinaman': Rex. V. Charles Lee Hing, Stratford, Ontario, 1909," in Ontario Since Confederation-- A Reader, ed. EdgarAndré Montigny and Lori Chambers, 147. 
unlawfully done so on multiple occasions, hiding his anti-Chinese sentiment under the pretext of saving white Canadians from "wily" Chinese behavior. ${ }^{70}$ A 1914 Kelowna Record article typical of many from the era describes a raid made "on a Chinese opium den," using racial slurs ("Chinamen") and describing how one "shouted an alarm as they heard the police coming." 71 These articles were common and, by publishing those where people were convicted, each underscored the apparent legitimacy of forcibly and unlawfully breaking into Chinese property by the police.

Newspaper coverage was biased, and often used words such as "another" or "again" when describing a Chinese person jailed for opium. ${ }^{72}$ Numerous media outlets told graphic stories of pretty young girls found in Chinese "dens," and these articles had such influence that Prime Minister King tabled a report warning about opium smoking spreading from the Chinese to white women and girls, quoting information from a newspaper story. ${ }^{73}$ Subsequently, legislation was passed less than a week later prohibiting the "manufacture, sale, and importation of opium for other than medical purposes" without debate. ${ }^{74}$

Michel Foucault's "themes of surveillance" argues that the need to constantly monitor people, as white people in the 1920s often did with their drug busts of Chinatowns, were motivated by the desire to regulate and control "sexuality and sexual practices."75 It fueled white Canadian racism to believe that "beneath the veneer of the smiling, harmless Chinaman lurked an evil so deep and so incomprehensible" that there was an "insurmountable distance between the white and yellow races"76 and no chance for assimilation. Further, the idea that the Chinese themselves created the partition fuelled the idea that these immigrants were themselves opposed to assimilation. ${ }^{77}$ This idea supported beliefs about Chinese exclusion legislation. The "façade" metaphor was constructed by writers, echoed both in the situation of Chinese shops and businesses and their own bodies-the idea that their friendly dispositions were just as deceptive as their non-threatening storefronts, but behind the partition they "ravished white women and plied them

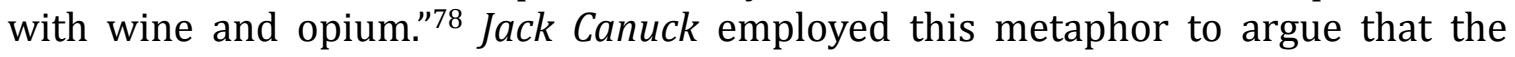

\footnotetext{
${ }^{70}$ Backhouse, "White Womans Laws" 324.

71 “Chinese Opium Den Raided by Police," August 27, 1914, Kelowna Record, British Columbia Historical Newspapers. UBC Library, 1.

72 April 12, 1917, Kelowna Record, British Columbia Historical Newspapers, UBC Library, 1.

${ }^{73}$ Carstairs, “Deporting 'Ah Sin,'” 69.

${ }^{74}$ Ibid.

75 Ibid, 92.

76 Ibid, 89.

77 Ibid.

78 Pon, “Construction of Chinese Masculinity," 89.
} 
"diminutive, smiling façade" of the "quaint" Chinamen hid the "true essence" of their character, fuelling fear and distrust. ${ }^{79}$

White supremacist anxieties about preserving the "racial and sexual purity of white womanhood" 80 arose in some capacity through regulating and controlling drugs and opium, associated as they were with Chinese men. Emily Murphy's campaign against drugs was framed as an effort to protect white women. Murphy believed that in situations where Chinese men were able to own their own businesses, "entrapment was likely to occur," and that "white women who sought work in Chinese restaurants were at particular risk." ${ }^{81}$ According to Murphy's influential 1922 anti-narcotics book, The Black Candle, race mixing was "an inevitable corollary to drug addiction" and "opium was initially an aphrodisiac," leading white women into sexual liaison with Chinese men that could lead to pregnancy, "but that prolonged addiction resulted in sexual impotence," ${ }^{82}$ which would threaten both the future fertility of these women and the ability of white male opium users to become fathers. Murphy claimed that drug use posed a serious threat to the white race, as it accounted for most cases of miscegenation. In subsequent articles, Murphy accused the Chinese of continuing their nefarious activities behind locked doors and in hidden passages despite the Opium and Narcotic Drug Act. ${ }^{83}$ "Cunning Chinamen" were accused of "spreading immorality" and "utter demoralization," ${ }^{4}$ ultimately robbing white women of their "childbearing abilities" and, by extension, endangering the "fertility of the British empire." ${ }^{85}$

Despite the labour market concerns that underlay many of the discriminatory measures taken against Chinese business owners, we cannot rule out some of the reasons and catalysts that moral reformers lobbied for "moral interests." ${ }^{86}$ Moral regulation, as a process of naturalizing some behaviours while marginalizing and proscribing others, ${ }^{87}$ introduces the concept of social censure as necessary to emphasize a particular behaviour as criminal or wicked. ${ }^{88}$ Since anxieties about "working-class sexuality and reproduction" were intense in the interwar period, ${ }^{89}$ these moral interests were widely supported by the white Canadian population. In

\footnotetext{
${ }^{79}$ Pon, "Construction of Chinese Masculinity," 93-94.

${ }^{80}$ Ibid, 95.

${ }^{81}$ Backhouse, "White Womans Laws," 340.

82 Pon, "Construction of Chinese Masculinity," 90.

${ }^{83}$ Carstairs, "Deporting 'Ah Sin,"” 71.

${ }^{84}$ Pon, "Construction of Chinese Masculinity," 90.

${ }^{85}$ Ibid, 95.

${ }^{86}$ Backhouse, "White Womans Laws," 332.

${ }^{87}$ Joan Sangster, "Incarcerating Bad Girls: The Regulation of Sexuality Through the Female Refuges Act in Ontario, 1920-1945," Journal of the History of

Sexuality 7, no. 2 (1996): 241.

${ }^{88}$ Sangster, "Incarcerating Bad Girls," 245.

${ }^{89}$ Ibid.
} 
this case, people such as Emily Murphy and religious Reverends of Methodist Social and Moral Reform supported the interest of protecting women from "suffering a fate worse than death" from working for Chinese employers. Emily Murphy spearheaded one of the many anti-drug campaigns in the 1920s, which also included large amounts of anti-Asian rhetoric. Reverend T. Albert Moore wrote in to the Regina Morning Leader, referencing a letter he had received from a "prominent citizen of Saskatoon," who deplored Chinese men's prevalence and "fondness" for working with white women throughout "the three prairie provinces and British Columbia," calling Chinese working environments the "underworld." These activists made it their mission to "combat social evils" to prevent Canadian women's loss of "decency" and protect Canada's reputation as a "moral nation." 90

Incidentally, many of the measures taken to protect women, including labour laws and moral reform, had the "unintended contradictory effects of punishing working-class women." 91 The intent of "protecting" working women from "perceived danger" by white middle-and upper-class social reformers ignored women working as chambermaids and domestics' mere desire to "hold on to their jobs." ${ }^{2}$ The 1912 Act to Prevent the Employment of Female Labour in Certain Capacities itself was not repealed until 1969,93 extending this problem well into the next generations of women, who found difficulty with finding employment as a result of racist laws rather than the economy. These working women resented the "aspersions cast upon their character by wealthier women" that "nice girls did not work for Orientals." 94 Working women themselves often actually embraced a more active version of femininity than the image of the vulnerable, powerless white women that progressives peddled. It is clear, then, that moral regulation was an upper class concern, which oppressed even the group it sought to aid.

Despite working women's rejection of being labeled victims, however, images of women's weakness and susceptibility to "Chinese charms and persuasions" prevailed. ${ }^{95}$ Jack Canuck emphasized the deceitful nature of Chinese men, who were constructed as having "evil leers" beneath their "bland smiles" and "quaint pidgin English," which women apparently could not see through and were thus deceived becoming victims of "evil deeds." ${ }^{6}$ Jack Canuck published an apparent "testimony" by a white woman who had fallen victim to a Chinaman's "degrading embrace," who was "lured" with gifts and opium by a supposedly "Christianized" Chinese man until she became an addict.97 White women's "gullibility" was therefore a concern for

\footnotetext{
90 Sangster, “Incarcerating Bad Girls,” 246.

${ }^{91}$ Ibid.

92 Backhouse, "White Womans Laws," 362.

93 Ibid, 315.

94 Ibid, 363.

95 Pon, "Construction of Chinese Masculinity," 94.

96 Ibid.

97 Ibid.
} 
activists. ${ }^{98}$ Even "Christianizing" as a method for assimilation was seen as dangerous because "it brought Chinamen into contact" with white female teachers, who were vulnerable and susceptible. ${ }^{99}$ The Toronto Daily Star warned that there was "Trouble in Sunday Schools," and that even if Christianity was adopted by the Chinese, there was no guarantee of protection of white girls because Chinese "instinct of centuries" was stronger than the implication of civilizing religion. ${ }^{100}$ Writers such as Fred Jarrett from Jack Canuck supported the implication that white girls should not teach "Chinamen" in Sunday schools, and that contact between them should be forbidden until the Chinese were fully assimilated into "honorable gentlemen."101 Thus, news publications maintained the position that white girls should not associate with "riffraff" from the Orient. ${ }^{102}$ This influenced public opinions that maintained that "miscegenation, white women's addiction to opium, and their resultant infertility and debauchery" 103 would be the inevitable outcomes of contact between the groups.

It is important to consider the impact that the view of Chinese immigrants as a menace had on the younger Canadian population. Ideas that older Chinese boys would be a corrupting influence upon white Canadian children impacted movements to segregate education, such as those enacted in British Columbia as early as 1902 to 1905, and the Victoria School Board's September 1922 movement to segregate Chinese students. ${ }^{104}$ We can see school segregation as a particular instance of extreme white supremacy that prioritizes the protection of white children in contrast to the "supposed moral and physical threat"105 that young Chinese boys were seen to pose. A common sentiment, echoed by City Council in 1914 Vancouver ,maintained that children "wantonly exposed to Oriental vices" at a young age would be "indelibly stamped" by "revolting incidents."106

Parental concern maintained that Chinese children were not only "diseased and unclean,"107 but that they posed a "moral threat" to white children in younger grades. ${ }^{108}$ An issue arose in 1908 when white residents threatened to pull their children out of the Rock Bay School after one of the older Chinese students was

\footnotetext{
${ }^{98}$ Ibid, 95.

99 Ibid.

${ }^{100}$ Ibid.

${ }^{101}$ Ibid.

102 Ibid.

${ }^{103}$ Ibid, 96. Education 2, no. 2 (1990).

${ }^{105}$ Stanley, “White Supremacy," 289.

${ }^{106}$ Ibid.

${ }^{107}$ Ibid.

108 Ibid, 290.
}

104 Timothy Stanley, "White Supremacy, Chinese Schooling, and School Segregation in Victoria: the Case of the Chinese Students' Strike, 1922-1923," Historical Studies in 
expelled for "drawing obscene pictures in the exercise books of little white children." ${ }^{109}$ Particularly singled out as vulnerable were white girls, who were the subject of a brief scare in 1909 about white girls teaching English in Vancouver's Chinatown. ${ }^{110}$ Concerns similar to these motivated Vancouver City Council's 1914 call for school segregation. ${ }^{111}$ One of the reasons there was so much anxiety surrounding segregation laws was that schools that were not segregated allowed chances for white girls to meet and date Chinese boys. Anxieties surrounding this were fictionalized in popular culture, one with one such example demonstrated in a novel published in the Vancouver Sun in 1921, which depicted a girl who has met a "Chinaman" in school and then eloped with him during the night, to the "shock and horror"112 of her parents. Her father placed the blame on "this damned system of coeducation."113

Ideas surrounding intermarriage and interracial courtship arose as a result of their presence in Canada. Theories of eugenics and white supremacy were prevalent during the late Victorian period, which meant white women were often constructed as the "guardians of the race," whose reproductive capabilities should be kept to white men and protected from the "encroachment of other races."114 The importance of British political and cultural ideals was present in the public discourse concerning the preservation of "racial purity."115 Despite Emily Murphy's position that intermarriages "were crimes against nature that threatened the mental health of white women,"116 there was a considerable amount of "mutually beneficial relationships" involving sex and romance between white women and Chinese immigrant men. ${ }^{117}$ While these relationships were not uncommon, public sentiment was not supportive of them and often reflected racist attitudes. No Canadian laws prohibited intermarriage, but the police had jailed a Chinese man in Diamond City, Alberta in 1911 because he had "proposed marriage to his white female employee."118 In fact, some historians have even found evidence that "for a Chinese man on the prairies, dating a white female could be enough to provoke talk of a lynching." ${ }^{119}$ The KKK's presence in Canada also squarely opposed intermarriage on

\footnotetext{
${ }^{109}$ Ibid.

110 Ibid.

${ }^{111}$ Ibid.

${ }^{112}$ Quoted in Stanley, "White Supremacy," 290.

113 Ibid.

114 Backhouse, “White Womans Laws," 336.

115 Chenier, "Sex, Intimacy and Desire," 30.

116 Pon, "Construction of Chinese Masculinity," 90.

117 Chenier, "Sex, Intimacy and Desire".

118 Backhouse, "White Womans Laws," 344.

${ }^{119}$ Backhouse, "White Womans Laws," 344.
} 
the ground of "racial purity," burning crosses and demanding a ban on marriage between white women and "negroes, Chinese or Japanese."120

Despite constructing the threat of the Chinese sexual predator, there was also an underlying misogyny in public discourse surrounding what was seen as women's sexual deviancy concerning interracial sex. Deviancy, here, was linked to "sex with nonwhite men." 121 In fact, women's "sexual nonconformity was literally equated with their insanity" ${ }^{122}$ Since promiscuity was defined only as a female problem, sexual guilt could be largely placed on women for having "the wrong kind of partner."123 This can be deduced from the common cases where young white women were found with Chinese men and referred to psychiatric care by magistrates, because of the increased intensity of "parental and police anxiety." 124 A case in the early thirties where a seventeen-year-old was found in a "bawdy house with a Chinaman"125 and was immediately referred to psychiatric care, as well as a 1938 case where an 18year-old domestic was let go from questioning with a warning to "stay out of Chinese restaurants"126 underscores this idea. These reactions were not uncommon. When women were older, even less leniency or blame on mental health was administered. A 22-year-old woman who had emigrated from England and had become pregnant after having sex with a Chinese man was deported. ${ }^{127}$ In cases of non-consensual relationships, women were not considered "astute enough" to "see the supposed danger lurking behind the Chinese façade."128 Even in consensual marriages, women who married interracially were widely considered "mentally unstable" prior to their marriage, and this state was considered to be worsened by their partners. ${ }^{129}$ In cases where both racial prejudice against Chinese men and anxiety around women's sexual nonconformity were in play, the punitive measures were more complicated than a simple racial scapegoat. In the 1909-1910 Ontario case of "One Good Chinaman," assimilation to Canadian behavior and nonconformity to behavioural expectations of "predatory Chinamen" allowed Charlie Hing to escape conviction in what had originally looked like a rape case "typical of fiendish Chinese behaviour"130 while Daisy Reid, his accuser, was dismissed as "yet another bad

${ }^{120}$ Constance Backhouse, 'It Will Be Quite an Object Lesson': R. v Phillips and the Ku Klux Klan in Oakville, Ontario, 1930," Colour Coded: a Legal History in Canada, 1900-1950, (1999), 169.

${ }^{121}$ Sangster, "Incarcerating Bad Girls," 257.

122 Ibid, 252.

${ }^{123}$ Ibid, 251.

${ }^{124}$ Ibid, 252.

125 Ibid.

${ }^{126}$ Ibid, 253.

${ }^{127}$ Ibid, 257.

${ }^{128}$ Pon, "Construction of Chinese Masculinity," 97.

${ }^{129}$ Ibid, 90.

${ }^{130}$ Pon, “One good Chinaman," 147. 
girl."131 Despite the intense racism Chinese men faced, there clearly were opportunities for them to rise above the prejudices placed against them through assimilation.

The social and economic oppression of the Chinese in Canada can be seen to be heavily based on sexually contingent narratives. Acts prohibiting the intermixing of races in a variety of environments can be related to white supremacist anxieties about corruption and demoralization by foreign men. Opportunities for assimilation, though available, were difficult and seen as ploys, and white Canadian's construction as victims furthered the moral panic for legislation against Chinese immigrant's access to and freedom within Canada. Thus, moral anxieties can be connected with much of the racist legislation enacted against Chinese male immigrants from 1900 until 1950, contextualizing the racism faced by this group at a deeply personal level.

131 Ibid. 


\section{Bibliography}

Backhouse, Constance. "The White Womans Labor Laws: Anti-Chinese Racism in Early Twentieth-Century Canada." in Law and History Review. Vol 14 no. 2

(Autumn, 1996): 315-368. http://library.mtroyal.ca:2055/stable/743786

“'It Will Be Quite an Object Lesson': R. v Phillips and the Ku Klux Klan in Oakville, Ontario, 1930." In Colour Coded: a Legal History in Canada, 1900-1950. University of Toronto Press. (1999): 173-225.

Carstairs, Catherine. "Deporting 'Ah Sin' to Save the White Race: Moral Panic, Racialization, and the Extension of Canadian Drug Laws in the 1920s." in Canadian Bulletin of Medical History. Volume 16: (1999): 65-88.

Chenier, Elise. "Sex, Intimacy, and Desire among Men of Chinese Heritage and Women of Non-Asian heritage in Toronto, 1910-1950." in Urban History Review 42, 2 (2014): 29-43. issn: 0703-0428 http://library.mtroyal.ca:2071/ehost/pdfviewer/pdfviewer?sid=c0819d64e29e-4ca9-81a8-f8a51886b455\%40sessionmgr4002\&vid=6\&hid=4114

Iacovetta, Franca. "From Newcomers to Dangerous Foreigners" in Gatekeepers: Reshaping Immigrant Lives in Cold War Canada. Toronto: Between the Lines, (2006,): 204-231.

"Jealous Chinaman murders white girl." The Toronto Star, August 6, 1909. Proquest Historical Newspapers: Toronto star (1894-2011).

"Chinese Opium Den Raided by Police." Kelowna Record, August 27, 1914. British Columbia Historical Newspapers. UBC Library. Page 1

Pon, Madge. "Like a Chinese Puzzle: The Construction of Chinese Masculinity in Jack Canuck." In Gender History in Canada. Joy Parr and Mark Rosenfeld, eds. Toronto: Copp Clark, (1996): 88-100.

Pon, Mona-Margaret. “The case of the 'one good chinaman': Rex. V. Charles Lee Hing, Stratford, Ontario, 1909." in Ontario Since Confederation-- A Reader- edited by Edgar-André Montigny and Lori Chambers. 147-165.

Sangster, Joan. 1996. "Incarcerating Bad Girls: The Regulation of Sexuality Through the Female Refuges Act in Ontario, 1920-1945" in Journal of the History of Sexuality 7(2) 239-275.

"Soldier Husband Lives." The Toronto Star, October 6, 1920. ProQuest Historical Newspapers: Toronto Star (1894-2011).

Stanley, Timothy. "White Supremacy, Chinese Schooling, and School Segregation in 
Weber, "Moral Panics" 64

Victoria: the Case of the Chinese Students' Strike, 1922-1923." in Historical Studies in Education. 2,2 (1990): 287-305. 